\title{
PENGEMBANGAN MEDIA PEMBELAJARAN AKUNTANSI KEUANGAN DALAM MENINGKATKAN PENGUASAAN KOMPETENSI VOKASIONAL MAHASISWA FAKULTAS PENDIDIKAN EKONOMI DAN BISNIS.
}

\author{
Oleh: \\ Kurjono \\ (Dosen Program Studi Pendidikan Akuntansi FPEB-UPI)
}

\begin{abstract}
Mata kuliah Akuntansi Keuangan Dasar 1 selanjutnya disebut mata kuliah AKD 1 adalah mata kuliah fakultas Pendidikan Ekonomi yang wajib diikuti oleh seluruh mahasiswa Fakultas Pendidikan Ekonomi dan Bisnis semua Jurusan. Berdasarkan pengalaman penulis, terungkap bahwa mahasiswa banyak mengalami kendali terutama dalam memahami konsep-konsep dasar serta kemampuan vokasional.

Berbagai hasil analisis ternyata untuk menguasai aspek-apek konsep dasar serta vokasional akuntansi dapat diperoleh melalui pemahaman materi melalui media yang relevan. Dalam hal ini pengenalan aspek materi akuntansi yang disajikan secara manual banyak menghambat terutama dalam mengalokasikan waktu. Oleh karena itu penulis menggunakan media komputer. Sedangkan untuk penguasaan vokasional akuntansi dilakukan melalui latihan verbal. Oleh karena itu penulis menggunakan media job sheet yang dirancang secara sistematis dan berjenjang.

Hasil penelitian menunjukkan bahwa untuk penguasaan konsep-konsep akuntansi ada perbedaaan dengan gain sebesa. sedangkan untuk penguasaan vokasional akuntansi ada perbedaan dengan gain sebesar. Dengan demikian dapat disimpulkan bahwa untuk penguasaan konsep dasar dapat digunakan media pembelajaran komputer sedangkan untuk penguasaan vokasional akuntansi dapat menggunakan media job sheet.
\end{abstract}

Kata kunci: Media, job sheet, pembelajaran akuntansi

\section{Pendahuluan}

Mata kuliah Akuntansi Keuangan Dasar 1 selanjutnya disebut mata kuliah AKD 1 adalah mata kuliah fakultas Pendidikan Ekonomi yang wajib diikuti oleh seluruh mahasiswa Fakultas Pendidikan Ekonomi dan Bisnis semua Jurusan. Diselenggarakan pada semester dua dan serentak di program studi Ekonomi Koperasi, Administrasi Perkantoran, Manajemen Bisnis, Manajemen, Pendidikan Akuntansi dan Akuntansi. Mata kuliah ini sifatnya wajib bagi semua jurusan, khususnya untuk jurusan pendidikan Akuntansi, mahasiswa selain harus lulus juga dianjurkan memiliki nilai sekurang-kurangnya B (kebijakan prodi pendidikan Akuntansi) kebijakan ini diambil mengingat untuk mahasiswa prodi pendidikan sebagai mata kuliah dasar bersyarat. Hal ini karena tugas calon guru tidak hanya menguasasi ilmu kependidikan namun juga harus menguasasi disiplin ilmu yang akan diajarkan.

Berdasarkan hasil analisis terhadap nilai mata kuliah AKD1, terungkap bahwa mahasiswa sulit memahami konsep-konsep pada mata kuliah Akuntansi keuangan secara utuh, sehingga pola belajarnya cenderung menghapal dan kurang memahami keterkaitan konsep-konsep . Suatu model pembelajaran yang mampu memvisualisasikan kesan yang abstrak diperlukan untuk meningkatkan pemahaman mahasiswa terhadap konsep esensial yang dipelajari.

Materi perkuliahan AKD.1 menitikberatkan pada bahasan tentang siklus akuntansi yang merupakan urutan kegiatan yang harus dilakukan mulai dari proses pencatatan, sampai penyusunan dalam laporan keuangan yang terdiri dari neraca dan laporan laba rugi perusahaan jasa dan dagang.
Oleh karena itu mahasiswa selain harus menguasai konsep dasar akuntansi juga harus terampil dalam mengerjakan pekerjaan klerikal yakni, menghitung serta menyajikan informasi keuangan mulai dari proses mencatat dengan berbagai jenis jurnal, buku besar, neraca lajur serta laporan keuangan secara cepat dan tepat .

Karakteristik tersebut menyebabkan kesulitan bagi mahasiswa karena penguasaan konsep harus disertai dengan keterampilan secara manual untuk menyajikan informasi keuangan. Dengan demikian penyampaian pesan materi untuk memberikan penguasaan konsep-konsep akuntansi dan keterampilan akuntansi (vokasional) salah satunya memerlukan penggunaan media yang tepat selain metode pembelajaran yang relevan.

Strategi pembelajaran yang diterapkan saat ini oleh sebagian besar dosen yang pada umumnya menggunakan strategi belajar mengajar yang tetap lebih berfokus pada dosen (teacher centered). Metode ini lebih tepat disebut sebagai metode konvensional, karena mahasiswa lebih terfokus pada menghapal konsep-konsep, namun tidak menguasai secara utuh vocational accounting. Sementara untuk menguasai keterampilan akuntansi persyaratan utamanya yakni pengusaaan konsepkonsep akuntansi mutlak diperlukan, sedangkan penguasaan keterampilan akuntansi dapat diperoleh melalui proses latihan yang terencana dan sistematis.

Dalam hal penguasaan keterampilan akuntansi yang dilakukan dengan penggunaan latihan telah banyak dilakukan studi penelitian. Penguasaan keterampilan akuntansi dengan hasil belajar yang baik telah dilakukan oleh Ikin Solikin (2005) melalui pemberian latihan berjenjang, dimulai 
dari soal latihan-latihan yang tingkat kesukaran paling mudah sampai paling sulit. Sementara Kurjono (2007) dengan menggunakan media pembelajaran Job sheet juga meningkatkan hasil belajar mahasiswa pendidikan akuntansi. Evaluasi dalam mata kuliah AKD 1 yang dilakukan dengan UTS dan UAS di dalamnya selalu melibatkan pengerjaan keterampilan akuntansi. Oleh karena itu dalam penelitian ini penulis menekankan pentingnya peran media dalam rangka meningkatkan penguasaaan konsep-konsep serta keterampilan akluntansi.

Berdasarkan observasi dari hasil tes akhir pada mata kuliah AKD 1 selalu diperoleh hasil yang tidak memuaskan. Secara umum tingkat kelulusan hanya mencapai $65 \%$ dari rata-rata seluruh program studi jurusan pendidikan akuntansi (Rekapitulasi data nilai DAK 1 seluruh jurusan di Fakultas Pendidikan Ekonomi dan Bisnis, 2008). Kondisi ini tidak dapat dibiarkan begitu saja, karena itu penanggungjawab mata kuliah ini harus mampu meningkatkan hasil belajarnya. Hasil belajar tersebut dapat diidentifikasi baik dari faktor intern maupun ekstern ( Syamsudin, 1999). Dari faktor intern dapat dipahami karena faktor mahasiswa yang mengikuti materi pembelajaran Akuntansi Keuangan yang tidak mempelajari sebelumnya di SMA di rumpun nonsosial atau MAN rumpun nonsosial. Demikian juga dari faktor ini kejenuhan yang diperoleh mahasiswa karena mata kuliah AKD 1 ada persepsi harus pintar matematika disampig ketepatan, kecermatan dan kerapihan dalam mengerjakan mata kuliah AKD 1. Akibat dari faktor intern ini, muncul dua kelompok ekstrim yaitu kelompok yang menguasai materi dengan cepat (quick learner) dan kelompok yang menguasai materi dengan lambat (slow leaner). Di samping itu dilihat dari aspek ekstern, kompetensi dosen mata kuliah AKD 1 tidak hanya cerdas dalam menguasai materi bahan ajar. Hal penting lainnya adalah menguasai aspek-aspek kependidikan seperti penyajian perkuliahan dengan menggunakan metode yang variatif maupun penggunaan media yang relevan.

Untuk meningkatkan hasil belajar mahasiswa, dosen mata kuliah AKD 1 selain dapat memilih dan menerapkan suatu strategi pembelajaran yang lebih efektif dalam meningkatkan kemampuan penguasaan konsep juga dituntut penggunaan media yang tepat dalam meningkatkan kemampuan vokasional. Mengingat beragamnya kemampuan kelas, maka dosen AKD 1 harus mencoba untuk menggunakan beberapa media yang berkaitan dengan proses pembelajaran latihan, karena kemampuan vokasional akuntansi cenderung menggunakan media yang berorientasi latihan, diantaranya adalah penerapan media dengan lembar kerja (Job Sheet) dan komputer akuntansi multi media untuk penguasaaan konsep-konsep akuntansi. Setelah itu barulah diberikan tugas-tugas dalam bentuk latihan untuk penguasaaan keterampilan akuntansi. Khusus untuk penguasaan konsep-konsep akuntansi dengan materi pembelajaran AKD 1 yang padat meliputi konsep dasar akuntansi, pencatatan/jurnal, posting dan buku besar, neraca saldo, neraca lajur dan jurnal penyesuaian, penyelesaian neraca lajur, laporan keuangan dan penyelesaian siklus akuntansi. Masing masing untuk perusahaan jasa dan dagang. Namun jumlah materi yang sangat padat dengan jumlah waktu yang terbatas tidak memungkinkan dosen dapat menyelesaikan tugas mengajar akuntansi dengan efektif melalui latihan dikelas. Oleh karena itu media dengan, job sheet dan komputer multimedia diharapkan dapat menyampaikan konsep-konsep dasar akuntansi. Berdasarkan latar belakang tersebut, maka masalah yang akan dikaji adalah:

“ Bagaimana perbedaan hasil belajar yang menggunakan media pembelajaran yakni dengan job sheet dan komputer akuntansi multimedia dalam penguasaan Vokasional Mahasiswa Fakultas Pendidikan Ekonomi dan Bisnis "

Rumusan masalah tersebut dapat dijabarkan ke dalam beberapa pertanyaan penelitian sebagai berikut:

1. Bagaimana karakteristik prestasi belajar dengan media job sheet akuntansi yang dikembangkan untuk meningkatkan penguasaaan vokasional akuntansi mahasiswa Fakultas Pendidian ekonomi dan Bisnis.

2. Bagaimana karakteristik prestasi belajar dengan media komputer akuntansi multi media yang dikembangkan untuk meningkatkan kemampuan konsep dasar akuntansi mahasiswa Fakultas Pendidikan Ekonomi dan Bisnis .

Dengan merujuk kepada teori Loree (1970:136) yakni dengan mengembalikannya kepada tiga komponen utama dari proses belajar mengajar ialah komponen (S) Stimulus- O (Organismic)- R (Response) yang digambarkan secara sistematik sebagai berikut:

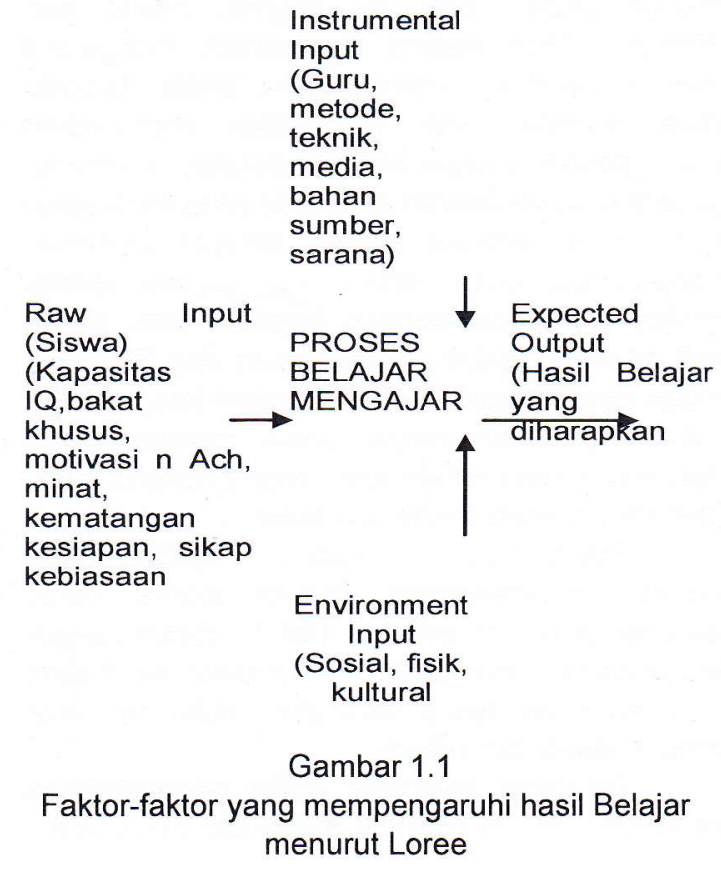


Faktor-faktor di atas saling berinteraksi secara langsung maupun tidak langsung dalam mempengaruhi prestasi belajar siswa. Salah satu faktor di atas adalah faktor eksternal adalah lingkungan sekolah serta instrumental input menurut Loree menujukkan bahwa media sebagai bagian dari instrumental input sangat mempengaruhi hasil belajar. Dalam penelitian ini penulis menjudge media yang aktual yaitu penggunaan komputer serta job sheet yang lebih sering digunakan dalam latihan-latihan untuk memperkuat vokasional. Dari teori besar di atas, selanjutnya pengembangan teori dilakukan oleh Thorndike dengan teori konektionisme dan Pavlov dengan nteori condotioning.

Dengan merujuk pada teori-teori tersebut selanjutnya dalam tataran aplikasi, kinerja guru dapat diidentifikasi melalui Instrumen Penilaian Kerja Guru untuk pelajaran Ekonomi Akuntansi, dimana secara garis besar dapat dikategorikan sebagai berikut:

I. Pra Pembelajaran

II. Membuka Pembelajaran

III. Kegiatan Inti Pembelajaran

1. Penguasaan materi pembelajaran

2. Strategi pembelajaran

3. Pemanfaatan sumber belajar/media pembelajaran

4. Pembelajaran yang memicu dan memelihara keterlibatan siswa

5. Penilaian proses dan hasil belajar

6. Penggunaan bahasa

IV. Penutup

(Dirjen Dikti, 2006)

Prestasi belajar merupakan kriteria dalam menentukan keberhasilan suatu kegiatan belajar mengajar. Prestasi ini menunjukan perubahan dalam diri siswa setelah mengalami Kegiatan Belajar mengajar (KBM) baik itu kognitif, afektif dan psikomotor. Oleh karena itu, setelah mengalami proses pendidikan dalam jangka waktu tertentu semua peserta didik diharapkan menunjukan perilaku positif sebagai prestasi belajar. Demikian juga dalam pembelajaran akuntansi yang melibatkan ketiga ranah tersebut diawali dengan pemahan konsep-konsep dasar akuntansi. Secara teoritis pemahaman konsep-konsep tersebut ada dalam ranah kognitif Ingatan, Pemahaman dan Evaluasi. Dengan demikian untuk menjembatani ketiga ranah di atas diperlukan media untuk menyampaikan pesan atau materi bahan ajar kepada peserta didik. Dalam hal ini dipilih media komputer.

Selanjutnya untuk meningkatkan penguasaaan vokasional, secara teoritis harus dilaksanakan latihan-latihan. Hal ini dalam rangka meningkatkan vokasional akuntansi digunakan media job sheet (yang bertingkat mulai dari soal mudah, sedang dan sukar).

Teknologi komputer mulai dikembangkan pada tahun 1950-an (Heinich, 1996) dan sejak saat itu komputer telah banyak menyumbangkan manfaat-manfaat luar biasa bagi kehidupan masyarakat. Sumbangan terbesar dalam bidang pendidikan sudah mulai dirasakan sejak lama, meskipun penggunaan komputer di sekolah-sekolah masih terbatas pada pengolahan kata (word processing) atau penghitungan lewat lembaranlembaran kerja (worksheef). Dengan melihat sudah banyaknya perguruan tinggi yang memiliki laboratorium akuntansi, sudah saatnya kini komputer didayagunakan untuk kepentingan pembelajaran akuntansi, bukan hanya sekedar menyelesaiakan masalah-masalah akuntansi tetapi juga memberi bantuan tentang cara penyampaian materi akuntansi itu sendiri dengan cara-cara yang menarik, menantang dan memperhatikan perbedaaan individual siswa.

Manfaat media pembelajaran job sheet adalah alternatif guru untuk mengelola dan mengarahkan proses pembelajaran, mengarahkan siswanya untuk menemukan konsep-konsep, meningkatkan motivasi siswa dalam belajar, meningkatkan minat belajar siswa, siswa tidak perlu mencatat atau membuat ringkasan pada buku catatannya dan mempermudah siswa untuk mengingat lebih lama apa yang dipelajarinya. Dari penjelasan itu jelaslah peningkatan kompetensi dapat dilakukan dengan latihan-latihan yang salah satunya dengan menggunakan job sheet.

Dengan menggunakan konsep dasar psikologis, khususnya dalam konteks pandangan Behaviourisme, kita dapat menyatukan bahwa praktek pendidikan pada hakekatnya merupakan usaha conditioning (penciptaan, seperangkat stimulus) yang diharapkan pula menghasilkan polapola perilaku (seperangkat response) tertentu. Prestasi belajar (achievement) dalam term-term pengetahuan (penalaran), sikap (penghayatan) dan keterampilan (pengamalan) merupakan indikatorindikator atau manifestasi dari perubahan dan perkembangan perilaku dimaksud. Dengan demikian apakah arah (positif, negative atau meragukan) dan perubahan dan perkembangan itu serta kualifikasinya (lulus/tidak lulus, memuaskan/tidak memuaskan, dapat diterima atau tidak) jelas tergantung pada faktor $S$ (conditioning, pendidikan) di samping faktor O (siswa, pelajar) itu sendiri. Kontribusi faktor-faktor $\mathrm{S}$ (pendidikan) dan $\mathrm{O}$ (karakteristik siswa sendiri) dapat digambarkan dengan formula matematis secara fungsional atau regresional yang notasinya sebagai berikut :

$P=f(S, O)$

$\mathrm{P}=\mathrm{a}+\mathrm{b} .1 \mathrm{~S}+\mathrm{b} .2 \mathrm{O}$ ( Pedoman Studi Psikologi

Pendidikan, 1990:24)

dimana

$P=$ Person (perilaku, pribadi); $f=$ funksi (function)

$\mathrm{S}=$ Stimulus (pendidikan);

$\mathrm{O}=$ Organisme (karakteristik siswa)

$A=$ konstanta (pengaruh rata-rata dari faktor $S$ dan

O) 
Telah dikemukakan bahwa salah satu tugas pokok dari guru ialah mengevaluasi taraf keberhasilan rencana dan pelaksanaan kegiatan belajar mengajar. Untuk menimbang sejauh mana taraf keberhasilan mengajar guru dan belajar siswa secara tepat, (valid) dan dapat dipercaya (reliable) kita memerlukan informasi yang didukung data yang obyektif dan memadai (adequate) tentang indikatorindikator perubahan perilaku dan pribadi siswa. Tentu sangat sulit untuk mengungkapkan segala aspek perubahan tersebut, mengingat bahwa belajar itu ada yang bersifat tangible dan intangible. Karena itu kita biasanya berusaha menambil cuplikan (sample of behavioral changes) saja yang diharapkan mencerminkan dari keseluruhan perubahan perilaku (population of behavoiral changes). Dengan demikian jelaslah bahwa sejauh mana kecermatan evaluasi (pertimbangan dan pengambilan keputusan serta diagnosa) kita atas taraf keberhasilan proses belajar mengajar itu akan tergantung kepada tingkat ketepatan, kepercayaan, keobyektifan dan kerepresentatifan informasi yang didukung oleh data yang diperoleh.

Komputer memiliki kelebihan yang tidak dimiliki media lain, misalnya komputer bisa memberikan pelayanan secara repetitif, menampilkan sajian dalam format dan desain yang menarik, animasi gambar dan suara yang baik dan melayani perbedaan individual. Seperti dikemukakan oleh Wilson(1998) bahwa komputer dengan desain software baik dalam menghadirkan presentasi secara berulang dan dinamis, karakteristik yang tidadk dijumpai dalam media lainnya.

Penggunaan software komputer untuk kegiatan pembelajaran sangat tidak terbatas (Fey dan Heid, 1984:21) dan potensi teknologi komputer sebagai media dalam pembelajaran akuntansi begitu besar (Fletcher, 1983:1). Banyak sekali kontribusi nyata yang dapat dipersembahakan komputer bagi kemajuan pendidikan, khususnya pelajaran akuntansi. Komputer dapat dimanfaatkan untuk mengatasi perbedaaan individual mahasiswa; mengajarkan konsep; melaksanakan perhitungan dan menstimulir belajar mahasiswa (Glass, 1984;11). Mahasiswa dapat mengatur kecepatan belajarnya, disesuaikan dengan tingkat kemampuannya. Mereka dapat mengulang beberapa kali sampai benar-benar menguasai materi yang harus dipahaminya. Ini sangat ideal bagi siswa yang sulit mengikuti pemebelajaran akuntansi, terutama mahasiswa yag tergolong slow learner. Bagi mahasiswa yang kemampuannya tinggi (fast learner), merek dapat diberi pengayaan (enrichment) sehingga mereka akan merasa lebih tertantang dan mendapat kesempatan untuk melakukan eksplorasi konsep secara lebih mendalam. Komputer dapat menuntun siswa mulai dari materi yang sederhana hingga yang amat komplek. Dengan bantuan programnya, komputer dapat memberi akses pada siswa untuk menganalisis dan mengeksplorasi konsep akuntansi; sehingga siswa memperoleh pemahaman yang lebih baik dalam konsep tersebut.

Beberapa kelebihan komputer yang sesuai dengan pembelajaran akuntansi adalah adanya kesabaran yang tiada batas, tidak terkait dengan perasaan manusia, mampu memotivasi siswa dengan pujian yang dirancang khusus, memberi kesempatan eksperimen tanpa dihantui kekuatiran akan kerusakan yang bisa terjadi, tidak diskriminatif, memberi siswa keterampilan yang berharga untuk masa depannya, mempercepat proses perhitungan yyang secara manusa sangat lama waktu penyelesaiannya atau bahkan tidak mungki sama sekali.

Beberapa penelitian (Kulik, 1985: dan Bangert-Drowns, 1985) memperlihatkan bahwa dibandingkan dengan pembelajaran konvensional, pembelajaran interaktif dengan media komputer memiliki beberapa keuntungan. Salah satu keuntungan tersebut diantaranya adalah penggunaan komputer yang tepat akan mampu meningkatkan kemampuan siswa dalam akuntansi, kecepatan siswa dalam penguasaan konsep yang dipelajarinya lebih tinggi, retensi siswa lebih lama, dan siskap siswa terhadap akuntansi menjadi lebih positif.

Komputer sebagai media pembelajaran, tidak sekedar berfungsi sebagai pembawa suasana dalam uansda yang baru, namun juga berperan secara positif dalam menumbuhkembangkan bakat dan minat siswa terhadap akuntansi. Suasana baru ini, yang terintegrasi dalam pembelajaran alternatif, mampu menimbulkan daya tarik tersendiri pada siswa sehingga mereka akan termotivasi mengikuti pembelajaran meskipun materi yang dihadapinya termasuk sulit.

Komputer sebagai media pembelajaran memiliki keunggulan-keunggulan yang tidak terdapat dalam media-media lainnya. Ini mencakup presentasi grafik, penjurnalan, buku besar dan laporan keuangan dalam tampilan yang menarik, yang dapat dimanipulasi secara leluasa dalam bentuk visual yang mempresentasikan model akuntansi. Bloom at all. (1987:1) dan Fletcher (1988:1) mengemukakan bahwa grafik resolusi tinggi dan program animasi memilki potensi yang amat besar untuk diaplikasikan dalam pembelajaran.

Penggunaan komputer disekolaj dapat dikalsifikasi dalam tiga model, yaitu penerapan komputer sebagai tutor, tool dan tutee. Sebagai tutor, komputer menuntun siswa dalam memahami konsep mulai mulai dari teori, teorema hingga ke pembuktian dan latihan sosal-soal. Sebagai tool (alat), komputer dapat dimanfaatkan oleh siswa untuk menyelesaikan masalah-massalah akuntansi. Siswa dapat menjalankan program komputer aplikasi khusus sesuai dengan konsep yang sedang dipelajarinya. Melalu program seperti ini siswa dimungkinkan untuk menelaah karakteristik suatu ide, misalnya bagaimana penjurnalan dari suatu transaksi dimodifikasi dimodifikasi dengan memanipulasi format jurnal dengan buku besarnya. Melalui pola ini siswa dilatih untuk mengalisis masing-masing transaksi keuangan dengan benar, sehingga mereka mampu memahami dan menerapkan transaksi tersebut dalam real world. 
Sebagai tutee, komputer berperilaku sebagi objek yang melaksanakan peritah mahasiswa, sehingga komputer mengikuti perintah dalam kendali mahasiswa, dan melakukan setiap tugas yang dibebankan kepadanya.

Rustaman (1999:5) mengemukakan bahwa "Media pembelajaran job sheet adalah media yang dapat mengaktifkan siswa untuk memperoleh dan mengembangkan konsep atau prinsip pembelajaran.

Dari definisi di atas dapat disimpulkan bahwa media pembelajaran job sheet adalah alat bantu belajar yang dibuat untuk mengefektifkan siswa dalam proses pembelajaran, berupa ringkasan materi, langkah-langkah untuk menyelesaikan tugas dan lembaran-lembaran berisi tugas yang harus dikerjakan siswa.

Media pembelajaran dapat mengefektifkan waktu siswa dalam belajar yang pada akhirnya dapat meningkatkan minat belajar siswa.

Manfaat media pembelajaran job sheet menurut Simangunsong (1994:14), yaitu sebagai berikut :

1. Memudahkan guru untuk mengelola proses pembelajaran

2. Membantu guru mengarahkan siswanya untuk menemukan konsep-konsep melalui aktivitasnya sendiri atau dalam kelompok kerja

3. Dapat digunakan untuk mengembangkan keterampilan proses, sikap serta membangkitkan minat belajar siswa

4. Memudahkan guru memantau keberhasilan siswa dalam mencapai sasaran belajar

Sedangkan menurut Setiawan (2002:2), manfaat-manfaat media pembelajaran job sheet, yaitu sebagai berikut :

1. Alternatif guru untuk mengarahkan proses pembelajaran

2. Mempercepat proses mengajar dan dapat menghemat waktu penyajian suatu topik

3. Siswa tidak perlu mencatat atau membuat ringkasan pada buku catatannya

4. Mempermudah penyelesaian tugas

5. Meningkatkan motivasi siswa dalam belajar

6. Meningkatkan minat belajar siswa

7. Mempermudah siswa untuk mengingat lebih lama apa yang dipelajarinya.

Dengan demikian, manfaat media pembelajaran job sheet adalah alternatif guru untuk mengelola dan mengarahkan proses pembelajaran, mengarahkan siswanya untuk menemukan konsepkonsep, meningkatkan motivasi siswa dalam belajar, meningkatkan minat belajar siswa, siswa tidak perlu mencatat atau membuat ringkasan pada buku catatannya dan mempermudah siswa untuk mengingat lebih lama apa yang dipelajarinya.

Media pembelajaran merupakan pendukung proses pembelajaran Akuntansi. Ketika guru dihadapkan dengan materi pembelajaran yang akan disajikan, guru harus mampu menyampaikan pesan-pesan dari materi pembelajaran. Oleh karena itu pesanpesan materi pembelajaran sangat beragam tergantung dari materi apa yang akan disampaikan guru.
Namun demikian media pembelajaran yang baik bukan hanya media yang mempertimbangkan kerelevanan dengan isi atau pesan materi pembelajaran saja, tetapi media pembelajaran juga harus mempertimbangkan faktor keaktualan dan kesesuaian dengan karakteristik siswa. Aktual artinya media tersebut harus sesui dengan perkembangan jaman, sedangkan karakteristik siswa artinya bahwa media pembelajaran yang digunakan dapat mempermudah siswa dalam memahami materi yang disajikan. Apabila penggunaan media berhasil sebagai sarana pendukung pembelajaran, pada akhirnya akan menghasilkan siswa yang sesuai dengan harapan sekolah.

\section{Metode Penelitian}

Untuk mengungkap berbagai faktor yang mempengaruhi prestasi belajar mahasiswa dalam mata kuliah Dasar Akuntansi keuangan I, peneliti menggunakan mahasiswa. Fakultas Pendidikan Ekonomi dan Bisnis dengan program studi Pendidikan Perkantoran kelas A. Hal ini karena pada program studi ini pengetahuan komputer lebih intensif dalam mata kuliah program studi. Adapun jumlah mahasiswanya sebanyak

Mereka adalah angkatan 2009 yang secara resmi mengikuti perkuliahan Akuntansi Keuangan Dasar I serta terdaftar di BAAK.

Model penelitian yang digunakan dalam penelitian ini adalah metode Pre-Experimental Designs (Sugiyono, 2004 : 82). Bentuknya adalah One Group Pretest-Postest Design Secara teoritis desain ini terdapat pre test sebelum perlakukan. Dengan demikian hasil perlakukan dapat dketahui lebih akurat, karena dapat membandingkan dengan keadaaan sebelum diberi perlakuan.

Mengingat dalam penelitian ini terdapat dua topik serta dua hipotesis yaitu topik penguasaaan konsep-konsep akuntansi (kognitif). Pada topik ini digunakan media komputer yang dirancang dan didesain untuk pembelajaran akuntansi keuangan dasar dengan pokok bahasan akuntansi perusahaan jasa. Sedangkan topik kedua yaitu penguasaaan vokasional akuntansi. Pada topik ini digunakan media job sheet yang dirancang dan didesain untuk pembelajaran akuntansi keuangan dasar dengan topik bahasan akuntansi perusahaan dagang.

Secara keseluruhan teknik-teknik penelitian yang penulis gunakan dalam penelitian ini digunakan Pengetesan. Tes dilakukan terhadap mahasiswa tingkat 1 program studi manajemen perkantoran kelas C dengan jumlah 52 mahasiswa, sesuai dengan jumlah sampel yang telah ditentukan sebelumnya.

Aspek yang diungkap dalam tes yaitu, mencakup; kemampuan penguasaan konsep dasar akuntansi dan kemampuan penguasaan vokasional akuntansi. Materinya terdiri dari:

Penguasaan konsep dasar akuntansi diberikan materi berupa: 
a) Konsep dasar siklus akuntansi perusahaan jasa

b) Penyelesaian siklus akuntansi perusahaan jasa

c) Jurnal umum

d) Buku besar dan Posting

e) Jurnal penyesuaian dan neraca saldo

f) Kertas kerja dan laporan Keuangan perusahaan jasa.

Penguasaan konsep vokasional akuntansi diberikan materi berupa:

a. Konsep dasar siklus akuntansi perusahaan jasa dagang

b. Penyelesaian siklus akuntansi perusahaan jasa dagang

c. Jurnal khusus

d. Buku besar dan Posting

e. Jurnal penyesuaian dan neraca saldo

f. Kertas kerja dan laporan Keuangan perusahaan dagang

Pembuatan kisi-kisi penguasaan konsep, dibuat dengan instrumen secara khusus yakni dengan menggunakan tes obyektif sedangkan untuk penguasaan aspek vokasional digunakan tes essay.

Populasi dalam penelitian ini adalah mahasiswa Fakultas Pendidikan Ekonomi Bisnis program studi pendidikan akuntansi dan administrasi perkantoran kelas c semester satul ganjil tahun ajaran 2009-2010 yang mengontrak mata kuliah Akuntansi Keuangan Dasar I. Untuk sampelnya digunakan secara random di fakultas pendidikan Ekonomi Bisnis, karena keenam jurusan tersebut dianggap mewakili untuk dapat mengikuti mata kuliah DAK.1. Diperoleh hasil undian penentuan sampel yaitu program studi Administrasi perkantoran.

Dalam penelitian ini digunakan beberapa instrumen yang dirancang untuk mengumpulkan data. Instrumennya digunakan untuk pengetesan adalah materi soal-soal akuntansi dasar 1, jobseheet akuntansi 1 serta cd untuk belajar mandiri di luar kampus. Sementara itu pada akhir penyelesaian studi, mahasiswa diberi alat tes soalsoal Akuntansi dengan tingkat kesukaran mudah, sedang dan sukar.

Berdasarkan paparan di atas maka hipotesis dalam penelitian ini adalah terdapat perbedaan sebelum dan sesudah penggunaan media pembelajaran jobsheet dan media komputer.

\section{Hasil Penelitian dan Pembahasan}

Program Studi Pendidikan Administrasi Perkantoran berjumlah 53 orang mahasiswa dengan jumlah 53 orang mahasiswa terdiri dari 38 mahasiswa perempuan dan 15 mahasiswa laki-laki. Kelas ini diberikan media pembelajaran komputer dan jobsheet. Sedangkan untuk metode pembelajarannya dilakukan metode latihan yang paling dominan.

Selanjutnya diadakan uji analisis soal dengan uji analisis soal dengan uji validitas. Dalam uji ini butir-butir soal yang valid digunakan untuk mentes responden sedangkan yang tidak valid diperbaiki.
Uji reliabilitas juga digunakan sebagai keajegan instrumen penelitian. Hasil uji reliabilitas ternyata instrumen tersebut reliabel, sehingga baik secara validitas dan reliabilitas instrumen dapat digunakan.

Khusus untuk soal pilihan ganda (objective test) analisis dilanjutkan dengan analisis taraf kesukaran dan daya pembeda. Setelah kedua hasil analisis ini diperbaiki terutama untuk daya pembeda yang kategori soal jelek diperbaiki lagi, maka selanjutnya diadakan uji normalitas dan homogenitas.Persyaratan statistik non parametrik yaitu uji normalitas dan homogenitas dapat dibuktikan, selanjutnya penulis mengadakan uji analisis hipotesis.

Hasil uji $\mathrm{t}$ berpasangan menyimpulkannya terdapat perbedaan yang signifikan antara pembelajaran sebelum dan sesudah menggunakan media komputer. Dengan demikian hipotesis pertama Ada perbedaaan hasil belajar sebelum dan setelah menggunakan media pembelajaran dengan komputer terbukti. Demikian juga hasil uji $t$ berpasangan menyimpulkannya terdapat perbedaan yang signifikan antara pembelajaran sebelum dan sesudah menggunakan media job sheet. Dengan demikian hipotesis kedua Ada perbedaaan hasil belajar sebelum dan setelah menggunakan media pembelajaran job sheet. Terbukti.

Deskripsi data dengan penggunaan media komputer menunjukkan nilai pretest sebesar rata-rat sebesar 66,22 sedangkan data setelah adanya perlakuan dengan media komputer meningkat menjadi 71. Nilai terendah sebesar 45 dan nilai tertinggi sebesar 85. Demikian juga data setelah diberi perlakuan. Rata-rata nilai sebesar 71 Nilai terendah postest sebesar 50 dan nilai tertinggi 90 . Angka-angka ini memberikan indikator adanya peningkatan hasil belajar dengan menggunakan media komputer.

Sedangkan dengan media job sheet diketahui bahwa nilai rata-rata yang diperoleh dengan metode jobsheet adalah 73,71 dengan nilai tertinggi 80 dan nilai terendah 60 .

Dari pembahasan tersebut, akhirnya penulis menemukan hasil penelitian

a. Peningkatan gain sebesar 5 dalam media pembelajaran komputer. Hal ini berarti bisa lebih ditingkatkan lagi apabila faktor-faktor lainnya dalam proses pembelajaran lebih diintensifkan. Misalnya dengan memberikan pengayaan.

b. Peningkatan gain sebesar 6 dalam media pembelajaran job sheet menunjukkan bahwa job sheet. Peningkatan gain bisa diperoleh dengan memberikan pengayaan serta diintensifkan proses belajar mengajar dengan asistensi baik oleh dosen asisten maupun oleh mahasiswa kawan setara.

c. Berdasarkan data ditemukan peningkatan nilai terendah dari 45 dengan media komputer pada sebelum perlakuan menjadi 50 setelah perlakukan. Demikian juga ditemukan peningkatan nilai terndah dari 50 menjadi 55 dalam media job sheet 
d. Nilai rata-rata dalam kurva normal pada media pembelajaran komputer antara 53- 60 meningkat menjadi 66-73. Sedangkan pada media job sheet nilai rata-rata dari rentang 56-61 meningkat menjadi 69-75.

\section{Simpulan dan Saran}

Dari hasil pembahasan, penulis menyimpulkan bahwa ada perbedaan hasil belajar dengan penggunaan model media komputer dan media pembelajaran dengan job sheet.

Dengan demikian penulis menyarankan bahwa pembelajaran akuntansi dengan media komputer maupun dengan media job sheet dapat dikembangkan dan diaplikasikan untuk meningkatkan penguasaaan konsep-konsep akuntansi dan penguasaan vokasional akuntansi.

\section{DAFTAR PUSTAKA}

Baridwan, Zaki (2003) Intermediate Accounting, BPFE Yogyakarta

Bloom, L.M.,Comber, G.A., and Cross, J.M (1987) Graphing Through Transformtion Via The Microcomputer. Bandung; PPPG.

Cony Semiawan. (1992). Pendekatan Keterampilan Proses. Jakarta: Gramedia

Fletcher, T.J.(1988) Microcomputers and Mathematics in School, United Kingdom, Department of Education and Science.

G. Anto Listianto. (2007). "Penggunaan Worksheet Untuk Pemahaman Akuntansi dan Pengembangan Softskills Mahasiswa". Makalah Diseminasi Hibah Model Pembelajaran. Maret. Yogyakarta

Glass, E.M. (1984) Computers; Challenge and Opportunity dalam Computer In Mathematics Education (Year book), Hansen, V.P. and Zweng, M.J (editors), Reston, Virginia; National Council of Teachers od Mathematics, Inc.

Hatfield, L.L.(1984) Toward Comprehensive Instructional Computing in Mathematics dalam Computers in Mathematics Education (year book) Hansen, V.P and Zweng, M.J (editors). Reston, Virginia; National Council of Teachers of Mathematics,

Heinich, R (1996) Intructional Media and Technology for Learning, New Jersey; Prentice Hall, Inc

Horngren dkk, Akuntansi di Indonesia, Buku satu, 1997, Salemba Empat

Moedjiono \& Moch Dimyati (2002) Strategi Belajar Mengajar, Jakarta Dedikbud.

Simangunsong. (1994). "Pengaruh Penggunaan LKS Terhadap Peningkatan Prestasi Belajar Siswa SD Kelas $V$ di Kabupaten Bandung Pada Mata Pelajaran IPA". Laporan Penelitian UPI. Bandung:

Sudirman, (1991) Ilmu Pendidikan, Bandung : Remaja Rosdakarya.

Sugiyono (2004) Metode Penelitian Administrasi. Bandung: Alfabeta.
Sukidin, (2002). Manajemen Penelitian Tindakan Kelas. Surabaya: Insan

Slavin, R. E. (1995). Cooperative Learning, Theory, Research and Practice. Massachusetts: Allyn and Boccon.

Syaiful Sagala ( 2004) Konsep dan Makna Pembelajaran, Alfabeta, Bandung.

Syaiful Bahri Djamarah \& Aswan Zain (2006) Strategi Belajar Mengajar, Jakarta: Rineka Cipta

The Liang Gie (1995). Cara Belajar yang Efisien jilid II. Yogyakarta: Liberty

UPI (2007) Kurikulum Ketentuan Pokok dan Struktur Program, UPI Tidak diterbitkan

Pendidikan Ekonomi (2007) Rekapitulasi data nilai DAK 1 seluruh prodi Pendidikan Ekonomi.FPIPS, UP

Weygant, Kiesso, Kimmel, Accounting Principles, 1999, Fifth Edition, John Wiley \& Sons, Inc

\section{Hasil Penelitian}

Ikin Solikin (2005) Meminimalkan Tingkat Kesalahan Dalam Mengerjakan Thapan Siklus Akuntansi Melalui Metode Pendekatan Pola Latihan Berjenjang Dalam Mata Kuliah Dasar Akuntansi I Pada Mahasiswa Pendidikan Akuntansi. Program Studi Pendidikan Akuntansi, Penelitian Hibah Pembinaan, Program Studi Pendidikan Akuntansi, Pendidikan Ekonomi, FPIPS UPI, tidak diterbitkan.

Imas Purnamasari (2008) Meningkatkan Kemampuan Berpikir Kritis Siswa melalui Job Sheet Akuntansi dalam Mata pelajaran Akuntansi SMA

Kurjono, dkk (2007) Meningkatkan Kualitas Pembelajaran Akuntansi Keuangan Dasar 1 Melalui Job Sheet Pada mahasiswa Program Studi Pendidikan Akuntansi, Penelitian Hibah Pembinaan, Program Studi Pendidikan Akuntansi, Pendidikan Ekonomi, FPIPS UPI, tidak diterbitkan.

Rochanah, Nanih (2008) Pengembangan Model Pembelajaran Berorientasi Kontruksivistik Untuk Meningkatkan Kualitas Pembelajaran Akuntansi Di SMA, Penelitian Dana Rutin tahun 2008, Universitas Pendidikan Indonesia 